Check for updates

Cite this: RSC Adv., 2019, 9, 255

www.rsc.org/advances

\title{
Correction: Click chemistry approaches to expand the repertoire of PEG-based fluorinated surfactants for droplet microfluidics
}

\author{
Randall Scanga, ${ }^{\text {a }}$ Lucie Chrastecka, ${ }^{\mathrm{b}}$ Ridhwan Mohammad, ${ }^{\mathrm{b}}$ Austin Meadows, \\ Phenix-Lan Quan ${ }^{\mathrm{b}}$ and Eric Brouzes*bc
}

Correction for 'Click chemistry approaches to expand the repertoire of PEG-based fluorinated surfactants for droplet microfluidics' by Randall Scanga et al., RSC Adv., 2018, 8, 12960-12974.

The authors regret that during production of the published version of their article the bold formatting in the NMR data to indicate the nuclei of interest was lost. The correctly formatted Synthesis section of the Materials and methods is presented below.

\section{Synthesis}

PFPE acid chloride (7)

The procedure for preparation of the PFPE acid chloride adheres to the previously published method with a few minor alterations $^{18,44}$ (see ESI). Starting with the commercially available end functional PFPE carboxylic acid Krytox FS(H) 157 (DuPont), the corresponding acid chloride is obtained by treatment with oxalyl chloride in refluxing methoxyperfluorobutane (HFE 7100, 3M). The newly generated acid chloride is isolated in situ under reduced pressure and redissolved in FC 3283. The resultant solution/ suspension is then filtered under inert atmosphere and used without further purification in the subsequent amidation reaction.

${ }^{19} \mathrm{~F}$ NMR $\left(\mathrm{C}_{6} \mathrm{D}_{6} / \mathrm{C}_{6} \mathrm{~F}_{6}, 282 \mathrm{MHz}\right) \delta \mathrm{ppm}:-80.67\left(\mathrm{~m}, 5 \mathrm{~F}, \mathrm{O}-\mathrm{CF}\left(\mathrm{CF}_{3}\right)-\mathrm{CF}_{2}\right),-81.96\left(\mathrm{~m}, 3 \mathrm{~F}, \mathrm{CF}_{3}-\mathrm{CF}_{2}-\mathrm{CF}_{2}\right),-82.57\left(\mathrm{~m}, 3 \mathrm{~F}, \mathrm{CF}_{3}-(\mathrm{CF})-\right.$ $\mathrm{C}=\mathrm{O}),-125.68\left(\mathrm{~m}, 1 \mathrm{~F}, \mathrm{CF}_{3}-(\mathrm{CF})-\mathrm{C}=\mathrm{O}\right),-130.48\left(\mathrm{~s}, 2 \mathrm{~F}, \mathrm{CF}_{3}-\mathrm{CF}_{2}-\mathrm{CF}_{2}\right),-144.87\left(\mathrm{~m}, 1 \mathrm{~F}, \mathrm{O}-\mathrm{CF}\left(\mathrm{CF}_{3}\right)-\mathrm{CF}_{2}\right)$.

\section{PFPE amides (8 and 9)}

The amidation reaction is performed in a biphasic solvent system comprised of FC 3283 and THF in the presence of TEA which serves as an $\mathrm{HCl}$ scavenger (see ESI and Holtze $e t$ al. ${ }^{18}$ ). The desired amine coupling partner dissolved in THF is added dropwise over $c a .30 \mathrm{~min}$ to the fluorocarbon phase resulting in the formation of a fine emulsion. After $c a .24 \mathrm{~h}$ the crude reaction mixture is isolated via rotary evaporation and once again redissolved in FC 3283 and filtered to obtain a clear, viscous, yellow oil.

Propargyl derivative (8) ${ }^{1} \mathrm{H}$ NMR $\left(\mathrm{C}_{6} \mathrm{D}_{6} / \mathrm{C}_{6} \mathrm{~F}_{6}, 300 \mathrm{MHz}\right) \delta \mathrm{ppm}$ : $6.58\left(\mathrm{br}, 1 \mathrm{H}, \mathrm{C}(\mathrm{O})-\mathrm{NH}-\mathrm{CH}_{2}\right), 4.12\left(\mathrm{~m}, 2 \mathrm{H}, \mathrm{O}-\mathrm{CH}_{2}-\mathrm{C} \equiv\right), 2.18$ $(\mathrm{t}, 1 \mathrm{H},-\mathrm{C} \equiv \mathbf{H})$.

${ }^{19} \mathrm{~F} \mathrm{NMR}\left(\mathrm{C}_{6} \mathrm{D}_{6} / \mathrm{C}_{6} \mathrm{~F}_{6}, 282 \mathrm{MHz}\right) \delta \mathrm{ppm}:-80.74\left(\mathrm{~m}, 5 \mathrm{~F}, \mathrm{O}-\mathrm{CF}\left(\mathrm{CF}_{3}\right)-\mathrm{CF}_{2}\right),-82.54\left(\mathrm{~m}, 3 \mathrm{~F}, \mathrm{CF}_{3}-\mathrm{CF}_{2}-\mathrm{CF}_{2}\right),-83.72\left(\mathrm{~m}, 3 \mathrm{~F}, \mathrm{CF} \mathbf{F}_{3}-(\mathrm{CF})-\right.$ $\mathrm{C}=\mathrm{O}),-130.47\left(\mathrm{~s}, 2 \mathrm{~F}, \mathrm{CF}_{3}-\mathrm{CF}_{2}-\mathrm{CF}_{2}\right),-133.39\left(\mathrm{~m}, 1 \mathrm{~F}, \mathrm{CF}_{3}-(\mathrm{CF})-\mathrm{C}=\mathrm{O}\right),-144.86\left(\mathrm{~m}, 1 \mathrm{~F}, \mathrm{O}-\mathrm{CF}_{(}\left(\mathrm{CF}_{3}\right)-\mathrm{CF}_{2}\right)$.

\section{CuAAC reactions}

\section{PFPE-PEG triazole linked triblock copolymer (12)}

$3.0 \mathrm{~mL}$ of methoxyperfluorobutane (HFE 7100) was added to $3.0 \mathrm{~g}(0.51 \mathrm{mmol})$ of PFPE-propargyl derivative and sonicated to obtain a clear, homogeneous solution. A solution of $164 \mathrm{mg}(0.27 \mathrm{mmol})$ of PEG 600 diazide in $1.5 \mathrm{~mL}$ of MeOH was prepared and sonicated. Next, $0.0102 \mathrm{~g}(0.051 \mathrm{mmol}, 10 \mathrm{~mol} \%) \mathrm{Cu}(\mathrm{OAc})_{2}$ and $17 \mathrm{mg}$ of neocuproine $(0.0815 \mathrm{mmol}, 16 \mathrm{~mol} \%)$ were added to the previously generated PEG 600 diazide/MeOH solution and further sonicated.

$20.2 \mathrm{mg}(0.102 \mathrm{mmol})$ of sodium ascorbate was then combined with $1.5 \mathrm{~mL}$ of DI $\mathrm{H}_{2} \mathrm{O}$, mixed and transferred to the PEG 600 diazide/ $\mathrm{Cu}(\mathrm{OAc})_{2} /$ neocuproine/MeOH solution. Finally, the combined solution was added to the PFPE-propargyl derivative/HFE

${ }^{a}$ Department of Chemistry, Massachusetts Institute of Technology, Cambridge, Massachusetts, USA. E-mail: randallscanga@yahoo.com

${ }^{b}$ Department of Biomedical Engineering, Stony Brook University, Stony Brook, New York, USA. E-mail: eric.brouzes@stonybrook.edu

${ }^{c}$ Laufer Center for Physical and Quantitative Biology, Stony Brook University, Stony Brook, New York, USA 
7100 solution in a single portion, and stirred at $1200 \mathrm{rpm}$ with a $1^{\prime \prime} \times 1 / 2^{\prime \prime}$ PTFE coated stir bar at room temperature (r.t.) for ca. $1 \mathrm{~h}$ before heating to $60{ }^{\circ} \mathrm{C}$. After $\mathrm{ca} .48 \mathrm{~h}, 6.0 \mathrm{~mL}$ of MeOH was added to the crude reaction mixture and stirred vigorously for $\mathrm{ca}$. 5 min. The resulting destabilized emulsion was left to stand until complete phase separation was noted. The fluorocarbon phase was then extracted and dried over $\mathrm{MgSO}_{4}$ under stirring for $c a .30 \mathrm{~min}$ before filtering through a $0.2 \mu \mathrm{m}$ PFTE syringe filter. Finally, solvent was removed under reduced pressure.

${ }^{1} \mathrm{H}$ NMR $\left(\mathrm{C}_{6} \mathrm{D}_{6}, 300 \mathrm{MHz}\right) \delta \mathrm{ppm}: 8.49\left(\mathrm{br}, 1 \mathrm{H}, \mathrm{C}(\mathrm{O})-\mathrm{NH}-\mathrm{CH}_{2}\right), 7.9\left(\mathrm{~s}, 1 \mathrm{H},-\mathrm{CH}_{2}-\mathrm{CN}=\mathrm{CH}-\right), 4.67\left(\mathrm{br}, 2 \mathrm{H},-\mathrm{NH}-\mathrm{CH}{ }_{2}-\mathrm{CN}=\right), 4.55$

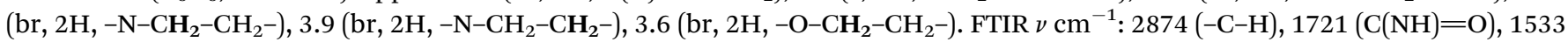
(amide II), 1306-1130 (C-F, C-O, overlapping).

\section{PFPE-PEG triazole linked tetrablock copolymer (14)}

A solution of $1.5 \mathrm{~mL}$ 2-(trifluoromethyl)-3-ethoxydodecafluorohexane (HFE 7500) and $1.5 \mathrm{~g}$ (0.254 mmol, 3.0 eq.) of PFPE-propargyl derivative was prepared. $95.6 \mathrm{mg}(0.0889 \mathrm{mmol}, 1.05 \mathrm{eq}$.) of glycerol ethoxylate triazide and $0.975 \mathrm{~mL}$ of $\mathrm{MeCN}$ was prepared and sonicated. Next, $0.00761 \mathrm{~g}(0.0381 \mathrm{mmol}, 15 \mathrm{~mol} \%) \mathrm{Cu}(\mathrm{OAc})_{2}$ and $40.8 \mathrm{mg}$ of tris-(benzyltriazolylmethyl)amine (TBTA) $(0.0815 \mathrm{mmol}, 16 \mathrm{~mol} \%)$ were added to the previously generated glycerol ethoxylate triazide/MeCN solution and sonicated. $17.6 \mathrm{mg}$ $(0.0889 \mathrm{mmol})$ of sodium ascorbate was then combined with $0.525 \mathrm{~mL}$ of $\mathrm{DI}_{2} \mathrm{O}$, mixed and transferred to the glycerol ethoxylate triazide $/ \mathrm{Cu}(\mathrm{OAc})_{2} / \mathrm{TBTA} / \mathrm{MeCN}$ solution. Finally, the combined solution was added to the PFPE-propargyl derivative/HFE 7500 solution in a single portion, and stirred at $1200 \mathrm{rpm}$ with a $1^{\prime \prime} \times 1 / 2^{\prime \prime}$ PTFE coated stir bar at r.t. for $c a .1 \mathrm{~h} \mathrm{before} \mathrm{heating} \mathrm{to} 80{ }^{\circ} \mathrm{C}$. After $c a .48 \mathrm{~h}, 6.0 \mathrm{~mL}$ of $\mathrm{MeOH}$ was added to the crude reaction mixture and further stirred for $c a .5 \mathrm{~min}$. Stirring was discontinued and the destabilized emulsion was left to phase separate. The fluorocarbon phase was then isolated and dried over $\mathrm{MgSO}_{4}$ under stirring for $\mathrm{ca} .30 \mathrm{~min}$ before filtering through a $0.2 \mu \mathrm{m}$ PFTE syringe filter. Finally, solvent was removed under reduced pressure at elevated temperature $\left(70-80{ }^{\circ} \mathrm{C}\right)$.

${ }^{1} \mathrm{H}$ NMR $\left(\mathrm{C}_{6} \mathrm{D}_{6}, 300 \mathrm{MHz}\right) \delta \mathrm{ppm}: 9.15\left(\mathrm{br}, 1 \mathrm{H}, \mathrm{C}(\mathrm{O})-\mathrm{NH}-\mathrm{CH}_{2}\right), 7.97\left(\mathrm{br}, 1 \mathrm{H},-\mathrm{CH}_{2}-\mathrm{CN}=\mathrm{CH}-\right), 4.57\left(\mathrm{br}, 2 \mathrm{H},-\mathrm{N}-\mathrm{CH}_{2}-\mathrm{CH}_{2}=\right), 3.54$ (br, $2 \mathrm{H},-\mathrm{O}-\mathrm{CH}_{2}-\mathrm{CH}_{2}-$ ).

\section{Thiol-yne reactions}

\section{Brush-like PFPE-PEG polymer (13)}

$2.0 \mathrm{~g}$ (0.34 mmol, 1 equiv.) of PFPE-propargyl derivative was dissolved in $7 \mathrm{~mL}$ of methoxyperfluorobutane. Next, $106.8 \mathrm{mg}$ (96 $\mu \mathrm{L}$, $0.34 \mathrm{mmol}, 1.0$ equiv.) of hexa(ethylene glycol)dithiol and $17.6 \mathrm{mg}(0.068 \mathrm{mmol}, 0.2$ equiv.) of 2,2-dimethoxy-2-phenylacetophenone DMPA were combined and immediately dissolved in $3.5 \mathrm{~mL}$ of MeOH. The DMPA/thiol/MeOH solution was then transferred to the previously generated PFPE-propargyl derivative/HFE 7100 solution and the vial sealed with a septum. The sealed vessel was then flushed under positive pressure of $\mathrm{N}_{2}$ and irradiated at $365 \mathrm{~nm}$ while stirring at $\mathrm{ca} .1200 \mathrm{rpm}$, at r.t. overnight. The following day the crude reaction mixture was combined with an equivalent volume of $\mathrm{MeOH}(10.5 \mathrm{~mL})$ and allowed to stand until complete phase separation was noted. The fluorous phase was then isolated and directly evaporated in vacuo to obtain a clear, colorless oil.

${ }^{1} \mathrm{H}$ NMR $\left(\mathrm{C}_{6} \mathrm{D}_{6}, 300 \mathrm{MHz}\right) \delta \mathrm{ppm}: 8.35\left(\mathrm{br}, 1 \mathrm{H}, \mathrm{C}(\mathrm{O})-\mathrm{NH}-\mathrm{CH}_{2}\right), 7.42\left(\mathrm{br}, 1 \mathrm{H},-\mathrm{NH}-\mathrm{CH}_{2}-\mathrm{CH}=\right), 6.24(\mathrm{br}, 1 \mathrm{H},-\mathrm{CH}=\mathrm{CH}-\mathrm{S}), 5.68$ (br, $1 \mathrm{H},-\mathrm{CH}=\mathrm{CH}-\mathrm{S}), 3.67$ (br, $\left.2 \mathrm{H},-\mathrm{O}-\mathrm{CH}_{2}-\mathrm{CH}_{2}-\right), 3.02\left(1 \mathrm{H},-\mathrm{CH}-\mathrm{CH}_{2}-\mathrm{S}\right), 2.84\left(1 \mathrm{H},-\mathrm{CH}-\mathrm{CH}_{2}-\mathrm{S}\right)$.

\section{Hyperbranched PFPE-PEG (15)}

$2.0 \mathrm{~g}$ (0.339 mmol, 2 equiv.) of PFPE-propargyl derivative was dissolved in $7 \mathrm{~mL}$ of methoxyperfluorobutane. Next, $314 \mathrm{mg}$ (0.285 mmol, 3.78 equiv.*) of glycerol ethoxylate trithiol and $17.4 \mathrm{mg}$ (0.0678 mmol, 0.2 equiv.) of 2,2-dimethoxy-2phenylacetophenone DMPA were combined and immediately dissolved in $3.5 \mathrm{~mL}$ of $\mathrm{MeOH}$. The DMPA/thiol/MeOH solution was then transferred to the previously generated PFPE-propargyl derivative/HFE 7100 solution and the vial sealed with a septum. The sealed vessel was then thoroughly flushed with $\mathrm{N}_{2}$ and irradiated at $365 \mathrm{~nm}$ under vigorous stirring, at r.t. overnight. After ca. $24 \mathrm{~h}$ the crude reaction mixture was combined with an equivalent volume of $\mathrm{MeOH}(10.5 \mathrm{~mL})$ and the phases were allowed to separate. Finally, the fluorous phase was extracted and evaporated in vacuo to obtain a clear, colorless oil. *Stoichiometry adjusted to account for the presence of disulfide.

${ }^{1} \mathrm{H}$ NMR $\left(\mathrm{C}_{6} \mathrm{D}_{6}, 300 \mathrm{MHz}\right) \delta \mathrm{ppm}: 8.68\left(\mathrm{br}, 1 \mathrm{H}, \mathrm{C}(\mathrm{O})-\mathrm{NH}-\mathrm{CH}_{2}\right), 7.84\left(\mathrm{br}, 1 \mathrm{H},-\mathrm{NH}-\mathrm{CH}_{2}-\mathrm{CH}=\right), 6.38(\mathrm{br}, 1 \mathrm{H},-\mathrm{CH}=\mathrm{CH}-\mathrm{S}), 5.68$ (br, $1 \mathrm{H},-\mathrm{CH}=\mathrm{CH}-\mathrm{S}), 3.75\left(2 \mathrm{H},-\mathrm{O}-\mathrm{CH}_{2}-\mathrm{CH}_{2}-\right), 3.09\left(1 \mathrm{H},-\mathrm{CH}-\mathrm{CH}_{2}-\mathrm{S}\right), 2.9\left(2 \mathrm{H},-\mathrm{CH}-\mathrm{CH} \mathbf{H}_{2}-\mathrm{S}\right)$.

The Royal Society of Chemistry apologises for these errors and any consequent inconvenience to authors and readers. 